\title{
Genetic analysis of reproductive performance of Frieswal cattle at Military Farm, Ambala
}

\author{
Jagdeep Kumar ${ }^{1}$, Y. P. Singh ${ }^{1}$, Sushil Kumar², Rajbir Singh ${ }^{1}$, Ravinder Kumar ${ }^{2}$ and Pradeep Kumar $^{1}$
}

1. Department of Animal Husbandry, College of Veterinary and Animal Sciences, Sardar Vallabhbhai Patel University of Agriculture \& Technology, Meerut, Uttar Pradesh, India; 2. Dairy Cattle Breeding Division, Central Institute for Research on Cattle, Meerut, Uttar Pradesh, India.

Corresponding author: Jagdeep Kumar, email: jagdeepkumar.kumar11@gmail.com,

YPS: ypsingh@gmail.com, RS: rajbirsinghsvbp@gmail.com, SK: chaturvedisk@gmail.com, RK: ravinder774@radiffemail.com,PK: pradeepkumar1496@gmail.com

Received: 04-02-2015, Revised: 18-05-2015, Accepted: 25-05-2015, Published online: 08-09-2015

doi: 10.14202/vetworld.2015.1032-1037 How to cite this article: Kumar J, Singh YP, Kumar S, Singh R, Kumar R, Kumar P. Genetic analysis of reproductive performance of Frieswal cattle at Military Farm, Ambala, Veterinary World 8(8): 1032-1037.

\begin{abstract}
Aim: This study was carried out to investigate the genetic analysis of reproductive performance of Frieswal cattle at Military Farm, Ambala.

Materials and Methods: A total number of 3005 lactation records of 1147 Frieswal cows over a period of 15 years extending from 1993 to 2007 were used to study at Military Dairy Farm, Ambala. The study period was divided into 5 period of 3 years each. The average performances of reproduction traits, effect of genetic and non-genetic factors were analyzed, and estimation of genetic and phenotypic parameters of reproduction traits was undertaken.

Results: The age at first calving (AFC) differed significantly across the periods of calving. The AFC was lowest during the third period (1999-2001) and longest in the first period (1993-95). The effect of season and period of calving, lactation order and regression of AFC on dry period, calving interval and service period was highly significant. The effect of sire was nonsignificant. The heritability estimates were low for almost all the traits under study. The service period had a high genetic correlation with dry period and calving interval. The dry period also found to have a low genetic correlation with calving interval in Frieswal cows. Service period had a high phenotypic correlation with dry period and very high with a calving interval. The phenotypic correlation between the dry period and calving interval was recognized high.
\end{abstract}

Conclusions: Low heritability estimate for the reproduction traits indicates that there is a very little additive genetic variance in these traits, and individual selection will not be helpful for improving them. Improvement may be brought through better feeding and management of cows by reducing the environmental variability.

Keywords: Frieswal cattle, non-genetics factors, age at first calving, service period.

\section{Introduction}

In the last four decades, Indian dairy sector has undergone a major shift, mainly due to the synthesis of high yielding crossbred strains, which are playing a very good role for increasing milk production of the country. Consequently, milk production in the country has increased over 5-fold (from mere 121.8 million tons in 2010-2011 to 127.9 million tons in 2011-2012) [1]. Beside of this impressive growth in milk production and highest milk producer of the world, there is a shortage of milk due to increasing more affluent population of urban. At present, per capita availability of milk is about $290 \mathrm{~g} / \mathrm{day}$, which is higher than the recommendations of Indian Council of Medical Research [1].

The estimated demand for milk by the year 2022 in India would be about 210 million tons [2]. The total milk production (i.e. 127.9 million tons) of India is contributed by 77 million lactating animals (35.6 million buffaloes, 30.7 million indigenous and 10.7 million crossbred cattle [1]. Of the total milk produced

Copyright: The authors. This article is an open access article licensed under the terms of the Creative Commons Attributin License (http:// creative commons.org/licenses/by/2.0) which permits unrestricted use, distribution and reproduction in any medium, provided the work is properly cited. in the country, $53.4,22.9,20.2$ and $3.5 \%$ is shared by buffaloes, crossbred cattle, indigenous cattle and goat respectively [3]. This increase in milk production in India has been mainly due to increase in the population of breedable cross bred cows (6.03 million vs. 14.06) and buffaloes (42.35 vs. 57.87 million) during the period 1987 to 2007 .

The success of a dairy herd depends on the level of reproduction performance of the animals. Milk production of a cow is a function of its genotype and the environment under which the animal is brought and maintained at given time and age. There are many non-genetic factors, which introduce bias in the estimation of genetic parameters. In the absence of accurate value of these traits, it becomes difficult to estimate the genetic parameters of the traits, which determine the optimum selection criteria for planned improvement of the crossbred animals [4]. In view of the above facts, this study was conducted on the Frieswal cows maintained at Military Farm, Ambala.

\section{Materials and Methods \\ Study area \\ Ambala district of Haryana lies between $30^{\circ}$ $10^{\prime}: 31^{\circ} 35^{\prime}$ north latitudes and $76^{\circ} 30^{\prime}: 77^{\circ} 10^{\prime}$ east}


longitudes. The climate of Ambala district can be classified as subtropical monsoon, mild and dry winter, hot summer and sub-humid which is mainly dry with very hot summer and cold winter except during monsoon season when moist air of oceanic origin penetrate into the district. The hot weather season starts from mid-March to last week of the June followed by the south-west monsoon, which lasts up to September. The transition period from September to November forms the post monsoon season. The winter season starts late in November and remains up to first week of March. The normal annual rainfall of the district is $1076 \mathrm{~mm}$ and is unevenly distributed over the area. The average rainy days are 44 . The south west monsoon sets in from last week of June and withdraws in the end of September, contributing about $81 \%$ of normal annual rainfall. July and August are the wettest months. Rest, 19\% rainfall, is received during the non-monsoon period in the wake of western disturbances and thunderstorms. Generally, rainfall in the district increases from southwest to northeast. The mean maximum temperature is $40.8^{\circ} \mathrm{C}$ (May and June) and mean minimum is $6.8^{\circ} \mathrm{C}$ (January) of the district [5].

\section{Data collection and analysis}

The data on reproduction traits, age at first calving (AFC), service period, dry period, and calving interval. Pertained to 1147 Frieswal cattle progeny of 64 Sires, over a period of 15 years (1993-2007). The total years were classified into five periods taking into three seasons Winter (November-February), Summer (March-June), Rainy (July-October) in accordance with agro-climatic condition of the study center. Generally, rainfall in the district increases from southwest to northeast. As the data were non-orthogonal with disproportionate sub-class numbers. The least squares means, heritability, genetic and phenotypic correlation and effects of genetic and non-genetic factors were estimated by using mixed model least squares and maximum likelihood program as suggested, by Harvey [6].

1.0. The following least squares model was used separately for analysis of variance of AFC:

$\mathrm{Y}_{\mathrm{ijkl}}=\mu+\mathrm{S}_{\mathrm{i}}+\mathrm{SB}_{\mathrm{j}}+\mathrm{PB}_{\mathrm{k}}+\mathrm{e}_{\mathrm{ijk} k}$

Where,

$\mathrm{Y}_{\mathrm{ijk}}=$ observation on $\mathrm{t}^{\text {th }}$ animal of $\mathrm{i}^{\text {th }}$ sire of $\mathrm{j}^{\text {th }}$ season of birth and $\mathrm{k}^{\text {th }}$ period of birth.

$\mu=$ overall population mean

$\mathrm{S}_{\mathrm{i}}=$ random effect due to $\mathrm{i}^{\text {th }}$ sire

$\mathrm{SB}_{\mathrm{j}}=$ fixed effect of $\mathrm{j}^{\text {th }}$ season of birth

$\mathrm{PB}_{\mathrm{k}}=$ fixed effect due to $\mathrm{k}^{\text {th }}$ period of birth

$\mathrm{e}_{\mathrm{ijkl}}=$ random error assumed to be normally and independently distributed with mean zero and variance $\sigma^{2}$.

The least squares model was used for remaining traits, i.e. dry period, calving interval and service period separately as given below:

Where,
$\mathrm{Y}_{\mathrm{ijklm}}=$ is the observation on $\mathrm{m}^{\text {th }}$ animal of $\mathrm{i}^{\text {th }}$ sire in $\mathrm{j}^{\text {th }}$ season of calving of $\mathrm{k}^{\text {th }}$ period of calving and $1^{\text {th }}$ lactation order.

$\mu=$ population mean

$\mathrm{S}_{\mathrm{i}}=$ random effect due to $\mathrm{i}^{\text {th }}$ sire

$\mathrm{SC}_{\mathrm{j}}=$ fixed effect of $\mathrm{j}^{\text {th }}$ season of calving

$\mathrm{PC}_{\mathrm{k}}=$ fixed effect of $\mathrm{k}^{\text {th }}$ period of calving

$\mathrm{LO}_{1}=$ fixed effect of $1^{\text {th }}$ lactation order

$\mathrm{b}_{1}=$ Linear regression of $\mathrm{AFC}$ on production and reproduction traits

$\mathrm{b}_{2}=$ Quadratic regression (Q) of age of first calving on production and reproduction trait

$\mathrm{e}_{\mathrm{ijk} k \mathrm{~m}}=$ random error

\section{Results and Discussion}

The overall least squares mean (Table-1) for AFC was estimated to be $980.41 \pm 8.22$ days and found to be in accordance with the reports of Yadav et al. [7] however, Hassan and Khan [8] reported higher AFC. The effect of season of calving on AFC was non significant. Animals born in rainy season had lowest (968.65 \pm 10.72 days) average AFC while those born in winter season had highest (987.92 \pm 10.25 days) average AFC (Table-1). Non-significant effect of season of birth on AFC was observed in previous studies $[7,9,10]$. The average AFC was found to be significantly different in difference periods. The animals those born during the third period (1999-2001) showed lower ( $925.54 \pm 12.16$ days) average AFC (Table-1). This variation indicates that AFC may be optimized with improvement in management. Singh; Dubey and Singh; Singh et al. $[9,10,11]$ also observed a significant effect of a period of birth on average AFC. However, Singh et al. [11] could not find the significant effect of period of calving on AFC. Statistical analysis of variance (Table-2) showed that the AFC had non-significant effect on lactation length. Similar finding was also reported in the Annual Report of Project Directorate on Cattle [12].

The least squares overall population mean of dry period was $115.29 \pm 8.83$ days. This estimate was higher than the estimates reported by Singh and Gurnani; Mukherjee [13,14]. The present estimate was

Table-1: Least square means of AFC.

\begin{tabular}{lcc}
\hline Factor & \multicolumn{2}{c}{ AFC } \\
\cline { 2 - 3 } Parameter & $\begin{array}{c}\text { Number of } \\
\text { observations }\end{array}$ & $\begin{array}{c}\text { Least squares } \\
\text { mean } \pm \text { SE (days) }\end{array}$ \\
\hline Overall mean $(\mu)$ & 1147 & $980.41 \pm 8.22$ \\
Period of calving & & \\
$\quad$ Period 1 (1993-1995) & 162 & $1064.38 \pm 19.51$ \\
Period 2 (1996-1998) & 211 & $983.83 \pm 15.21$ \\
Period 3 (1999-2001) & 429 & $925.54 \pm 12.16$ \\
Period 4 (2002-2004) & 219 & $976.49 \pm 14.24$ \\
Period 5 (2005-2007) & 126 & $951.82 \pm 18.24$ \\
Season of calving & & \\
$\quad$ Winter & 478 & $987.92 \pm 10.25$ \\
(November-February) & & \\
Summer (March-June) & 227 & $984.67 \pm 13.05$ \\
Rainy (July-October) & 442 & $968.65 \pm 10.72$ \\
\hline AFC=Age at first calving, SE=Standard error
\end{tabular}

$\mathrm{AFC}=$ Age at first calving, $\mathrm{SE}=$ Standard error 
less than the estimates reported by Hassan and Khan; Singh [8,9] and Yadav et al.; Dubey and Singh [7,10]. Approximately, similar dry period i.e. $138.00 \pm 10.42$, $133.00 \pm 12.30,142.00 \pm 2.56$ and $130.40 \pm 0.67$ day was reported in FXJXJ crosses and in HFXS [15] and in Annual Report of Project Directorate on Cattle [12]. The season of calving had a significant influence on the dry period. Animals calved in rainy season had a shortest dry period (109.13 \pm 9.19 days) and those calved summer season had a longest dry period (118.54 \pm 9.26 days). Yadav et al.; Dubey and Singh $[7,10]$ reported non-significant effect of season of calving on this trait. The period of calving was found to have a highly significant influence on dry period. However, Dubey and Singh; Hadge et al. $[10,16]$ reported a significant effect of a period of calving on dry period. Results presented in Table- 3 indicated that the dry period was shortest in sixth lactation and it was longest in first lactation. The statistical analysis of data showed the highly significant effect of lactation order on dry period. Singh [9] also reported a significant effect of parity order on dry period. The AFC was not found to have a non-significant influence on dry period. The overall least squares mean of calving interval was $423.05 \pm 12.24$ days and this estimate was near to the values reported by Nayak and Raheja; Rathi and annual report of Project Directorate on Cattle $[15,17,18]$.

Table-2: Analysis of variance for AFC in Frieswal cows.

\begin{tabular}{lcc}
\hline Source & \multicolumn{2}{c}{ AFC } \\
\cline { 2 - 3 } & d.f. & Mean squares \\
\hline Sire & 56 & $48644.27^{* *}$ \\
Season of calving & 2 & 38352.04 \\
Period of calving & 4 & $270539.76^{* *}$ \\
Error & 1084 & 27243.04 \\
\hline
\end{tabular}

$* * \mathrm{p}<0.01, * \mathrm{p}<0.05 . \mathrm{AFC}=$ Age at first calving
The estimated value was more than the values reported by some workers $[10,13,14,19,20]$. However, higher values than the present study were reported by Yadav et $a l . ;$ Kabir and Islam [7,21].

Season of calving was found to have highly significant effect on calving interval. The highest average calving interval of $443.11 \pm 12.70$ days was observed in summer season of calving, while it was lowest $(409.21 \pm 12.62$ days $)$ in rainy season Hassan and Khan [8] also reported significant effect of season of calving on this trait. However, Yadav et al.; Dubey and Singh $[7,10]$ reported non-significant effect of season of calving on calving interval. Period of calving was found to have non-significant effect on calving interval (Table-4). The calving interval on an average was highest (428.14 \pm 13.69 days) during second period (19961998 ) and was lowest ( $414.97 \pm 12.46$ days) during third period (1999-2001). Singh; Dubey and Singh [9,10] also observed significant effect of period of calving on calving interval. Lactation order was found to have non-significant effect on calving interval (Table-4). Highest average calving interval of $439.77 \pm 10.05$ days was found in first lactation, while lowest average calving interval of $396.37 \pm 22.96$ days was found in sixth lactation. There was no definite trend in average calving interval during different lactation. Singh; Khanna and Singh; Tadesse and Dessie [9,22,23] also reported significant effect of parity order on calving interval. The AFC was found to have non-significant effect on calving interval (Table-4). The overall least squares mean of service period was $148.24 \pm 12.66$ days (Table-3). Approximately same service period i.e. $143.00 \pm 11.00$, $147.90 \pm 6.00,151.07 \pm 13.23$ days were reported by Singh and Gurnani; Kumar et al. [13,20], respectively reported the similar trend whereas the lower service

Table-3: Least square means of dry period, calving interval and service period.

\begin{tabular}{|c|c|c|c|c|}
\hline \multirow[t]{2}{*}{ Factor } & \multirow{2}{*}{$\begin{array}{l}\text { Number of } \\
\text { observation }\end{array}$} & \multicolumn{3}{|c|}{ Least squires mean } \\
\hline & & $\begin{array}{l}\text { Dry period } \pm \text { SE } \\
\text { (days) }\end{array}$ & $\begin{array}{c}\text { Calving interval } \pm \text { SE } \\
\text { (days) }\end{array}$ & $\begin{array}{c}\text { Service period } \pm \text { SE } \\
\text { (days) }\end{array}$ \\
\hline Overall mean $(\mu)$ & 1796 & $115.29 \pm 8.83$ & $423.05 \pm 12.24$ & $148.24 \pm 12.66$ \\
\hline \multicolumn{5}{|l|}{ Season of calving } \\
\hline Winter (November-February) & 696 & $118.20 \pm 9.07$ & $416.83 \pm 12.50$ & $142.29 \pm 12.95$ \\
\hline Summer (March-June) & 501 & $118.54 \pm 9.26$ & $443.11 \pm 12.70$ & $169.59 \pm 13.17$ \\
\hline Rainey (July-October) & 599 & $109.13 \pm 9.19$ & $409.21 \pm 12.62$ & $132.83 \pm 13.08$ \\
\hline \multicolumn{5}{|l|}{ Period of calving } \\
\hline Period 1 (1993-1995) & 159 & $107.17 \pm 11.56$ & $423.99 \pm 15.24$ & $142.67 \pm 15.95$ \\
\hline Period 2 (1996-1998) & 353 & $126.73 \pm 10.16$ & $428.14 \pm 13.69$ & $154.42 \pm 14.25$ \\
\hline Period 3 (1999-2001) & 784 & $109.76 \pm 9.04$ & $414.97 \pm 12.46$ & $142.79 \pm 12.91$ \\
\hline Period 4 (2002-2004) & 432 & $114.24 \pm 9.11$ & $421.42 \pm 12.54$ & $148.12 \pm 12.99$ \\
\hline Period 5 (2005-2007) & 68 & $118.54 \pm 12.06$ & $426.73 \pm 15.80$ & $153.18 \pm 16.56$ \\
\hline \multicolumn{5}{|l|}{ Lactation order } \\
\hline 1 & 709 & $139.26 \pm 6.70$ & $439.77 \pm 10.05$ & $169.03 \pm 10.22$ \\
\hline 2 & 488 & $108.72 \pm 5.08$ & $430.76 \pm 8.53$ & $155.06 \pm 8.50$ \\
\hline 3 & 329 & $110.47 \pm 6.34$ & $421.61 \pm 9.69$ & $144.68 \pm 9.82$ \\
\hline 4 & 178 & $111.87 \pm 9.12$ & $426.99 \pm 12.55$ & $150.45 \pm 13.00$ \\
\hline 5 & 64 & $110.71 \pm 13.22$ & $431.55 \pm 17.12$ & $155.89 \pm 18.00$ \\
\hline 6 & 25 & $106.51 \pm 18.25$ & $396.37 \pm 22.96$ & $122.00 \pm 24.31$ \\
\hline 7 and above & 3 & $119.50 \pm 43.15$ & $414.31 \pm 52.80$ & $140.55 \pm 56.33$ \\
\hline Regressions AFC & & & & \\
\hline
\end{tabular}

$\mathrm{AFC}=$ Age at first calving, $\mathrm{SE}=$ Standard error 
Table-4: Analysis of variance for dry period, calving interval and service period in Frieswal cows.

\begin{tabular}{lcccc}
\hline Source & d.f & \multicolumn{2}{c}{ Mean squares } \\
\cline { 2 - 4 } & & Dry period & Calving interval & Service period \\
\hline Sire & 64 & 5169.83 & 9167.46 & 9991.29 \\
Season of calving & 2 & $14829.89 *$ & $151845.92 * *$ & $174507.88^{* *}$ \\
Period of calving & 4 & $16765.34 * *$ & 9409.08 & 8407.96 \\
Lactation order & 6 & $28929.81^{* *}$ & 7648.67 & 11466.76 \\
Regressions AFC & 1 & 2007.00 & 8850.21 & 9241.30 \\
Error & 1718 & 4880.66 & 7218.61 & 8242.93 \\
\hline
\end{tabular}

$* * \mathrm{p}<0.01, * \mathrm{p}<0.05$. AFC $=$ Age at first calving

period than the present finding were reported by Singh and Gurnani; Mukherjee [13,14]. Although higher estimates than the present report were also reported by Dubey and Singh; Dandapat et al. $[10,24]$ in crossbred cattle. The season of calving was found to have highly significant effect $(\mathrm{p} \leq 0.01)$ on service period (Table-4). The differences among seasons may be due to the quality and availability of green fodder in different seasons. Results reflected that animals calved in summer season (March to June) had longest service period (169.59 \pm 13.17 days), whereas those calved in Rainy season (July to October) had shortest service period (132.83 \pm 13.08 days) (Table-3). Dubey and Singh [10] found no significant variations in service period due to season of calving. The period of calving had non-significant effect on service period (Table-4). The service period varied from $142.67 \pm 15.95$ days during first period (i.e. 1993-1995) to $154.42 \pm 14.25$ days during second period (i.e. 1996-1998) (Table-3). Significant effect of period of calving on service period was reported by Singh; Dubey and Singh $[9,10]$. The lactation order was found to have non-significant effect on service period. The service period on an average was highest ( $169.03 \pm 10.22$ days) of the animals those calved first time and it was lowest $(122.00 \pm 24.31$ days) of the animals those calved six time (Table-3). Singh; Khanna and Singh [9,22] also observed significant effect of parity on service period in crossbred cattle. The AFC was found to have non-significant effect on service period (Table-4). Effect of sire was found non-significant on the all productive and reproductive traits under the study.

The heritability estimates of different reproduction traits in Freiswal Cattle are presented in (Table-5). In general, heritability estimates reported in the present study was a lower value. It indicates that trait is influenced by environmental variation and may be improved by minimizing the environmental variation. The heritability estimate of AFC in the present study was very low $(0.15 \pm 0.065)$. Higher estimates of heritability than the present findings were reported by Mukherjee; Rathi; Chaudhary $[14,17,25]$ in HF crosses. Almost similar heritability estimates were reported in an annual report [12] in HFXS. Dry period had very low heritability estimate $(0.009 \pm 0.028)$. This estimate was comparable to those reported by Butte and Deshpande [19] in JXS. Higher estimates of heritability
Table-5: Heritability estimate of different reproduction traits in Frieswal cows.

\begin{tabular}{lc}
\hline Trait & Heritability $\left(\mathbf{h}^{2} \pm \mathbf{S E}\right)$ \\
\hline AFC & $0.15 \pm 0.065$ \\
Dry period & $0.009 \pm 0.028$ \\
Calving interval & $0.04 \pm 0.033$ \\
Service period & $0.03 \pm 0.032$ \\
\hline
\end{tabular}

$\mathrm{AFC}=$ Age at first calving, $\mathrm{SE}=$ Standard error

of dry period were reported by Chaudhary [25] in JXS, Mukherjee [14] in Friesian crosses, and low heritability, were estimated by Singh and Gurnani, Hadge et al.; Khan et al. $[13,16,26]$ in FXT and BSXS and annual report [12] in HFXS. The heritability of calving interval in Frieswal cattle was very low $(0.04 \pm 0.033)$, and was almost similar to those reported by Singh and Rathi $[13,17$,$] in BSXS and Mukherjee [14] in FXS.$ Comparatively higher heritability were reported by Chaudhary [25] in JXS and FXS, Khan et al. [26] in FXS, Dubey and Singh [10] in SXCB and Singh [11]. The low heritability estimate of service period $(0.03 \pm 0.032)$, revealed that the service period of Frieswal may further be improved by improving feeding and management including proper heat detection, timely insemination, and pregnancy diagnosis, and estimate was similar to reported by Mukherjee [14] in FXS. However, higher heritability estimates were reported by Dubey and Singh [10] in SXCB.

The present study pertains to the estimation of genotypic and phenotypic correlations among different reproduction traits with a view to investigate whether any association exists between the reproductive traits in Freiswal Cattle maintained at Military Dairy farm Ambala. The correlation between two traits was estimated by the method of analysis of variance and covariance by paternal half-sib analysis. The genetic correlation between two characters arises due to the pleiotropic effect of gene and some linkage among genes. However, in a large population under random mating, the effect of linkage in quantitative genes is expected to be negligible. Phenotypic correlations between two traits are a function of genetic and environmental correlations between them with the assumption that there is no covariance between genotype and environment. The genetic and phenotypic correlation coefficients among various reproductive traits are presented in (Table-6). Service period was 
Table-6: Genetic ( $\left.r_{g} \pm s e\right)$ (above diagonal) and phenotypic $\left(r_{p}\right)$ (below diagonal) correlations among service period, dry period and calving interval in Frieswal cows

\begin{tabular}{lccc}
\hline Parameter & $\begin{array}{c}\text { Service } \\
\text { period }\end{array}$ & Dry period & $\begin{array}{c}\text { Calving } \\
\text { interval }\end{array}$ \\
\hline Service period & - & $0.161 \pm 1.246$ & $0.910 \pm 0.102$ \\
Dry period & 0.612 & - & $0.137 \pm 1.162$ \\
Calving interval & 0.934 & 0.672 & - \\
\hline
\end{tabular}

found to have a high positive genetic correlation with dry period and calving interval. The corresponding estimates were $0.16 \pm 1.24$ and $0.91 \pm 0.10$. Dubey and Singh [10] reported medium $(0.57 \pm 0.14)$, Saha [27] reported low $(0.18 \pm 0.28)$ genetic correlation between service period and dry period. Singh and Gurnani [13] also found very high $(0.91 \pm 0.13)$ genetic correlation between service period and calving interval. The phenotypic correlations with dry period $(0.61)$ and calving interval (0.93) were high and was similar to as reported by Singh and Gurnani; Saha [13,27].

\section{Conclusion}

The average AFC was found to be a significant difference in different periods. The highest dry period was noted in summer season while the rainy season had the lowest. The calving interval proved to be dependent in its expression on year, the season of calving and parity of cow. The season of calving was found to have a highly significant effect on service period, and there was no effected by period of calving and parity of cow. In general, the heritabilities for all reproductive traits with the exception of AFC were low. From the results of this study, it may be concluded that proper feeding and management is necessary for the improvement of reproductive traits of Frieswal.

\section{Authors' Contributions}

YPS planned the study. JK recorded the information and analyzed the data. SK, RS, RK, and PK provided help in analyzing the data. JK drafted and revised the manuscript under the guidance of SK and YPS. All authors read and approved the final manuscript.

\section{Acknowledgments}

The authors are highly thankful to the Director, Central Institute for Research on Cattle, Meerut for providing necessary data on Frieswal cattle located at Military Farm Ambala.

\section{Competing Interests} interests.

The authors declare that they have no competing

\section{References}

1. Annual Report. (2012) Basic Animal Husbandry Statistics. Department of animal Husbandry, Dairying \& Fisheries Ministry of Agriculture, Government Of India, New Delhi, India. p52-53.
2. 19 Livestock Census. (2012) Salient Features Of $19^{\text {th }}$ Livestock Census. Ministry of Agriculture Department of Animal Husbandry, Dairying and Fisheries Krishi Bhawan, New Delhi, India. p11-12.

3. Mishra, A.K. (2012) Current and emerging reproductive biotechnology for enhancing milk productivity, Problems and Prospect. Deptt. Of Gynaecology and Obstetrics, College of Vet. and Animal Sci., GBPUAT, Pantnager, Uttarakhand, India.

4. Tomar, S.S. (2004) Textbook of Animal Breding. Kalyani Publisher, New Delhi, India. p90-94.

5. Khan, S.A. (2007) Central Ground Water Board Ministry of Water Resources Government of India North Western Region Chandigarh, India. p6-7-8.

6. Harvey, WR. (1991). User's guide for LSMLMW, mixed model least squares and maximum likelihood computer programme [mimeograph]. Columbus $(\mathrm{OH})$ : Ohio State University

7. Yadav, J.S., Dutt, G. and Yadav, M.C. (2004) Genetic studies of some lactation traits in crossbred cows. Indian $J$. Anim. Sci., 74(2): 1232-1233.

8. Hassan, F. and Khan, M.S. (2013) Performance of crossbred dairy cattle at military dairy farms in Pakistan. J. Anim Plant Sci., 23(3): 705-714.

9. Singh, Y. (2012) Studies on productive and reproductive performance of Frieswal Cattle. M.Sc. (Ag.) Thesis, Sardar Vallabhbhai Patel University of Agricultural \& Technology, Modipuram. Meerut (India).

10. Dubey, P.P. and Singh, C.V. (2005) Estimates of genetic and phenotypic parameters considering first lactation and lifetime performance traits in Sahiwal and crossbred cattle. Indian J. Anim. Sci., 75(11): 1289-1294.

11. Singh, U., Kumar, A., Beniwal, B.K. and Vinoo, R. (2008) Estimation of genetic parameters for economic traits in Ongole Cattle. Indian Vet. J., 85: 167-169.

12. Annual Report. (2011-12) Project Directorate on Cattle, Meerut, Uttar Pradesh, India.

13. Singh, M.K., Gurnani, M. (2004) Performance evaluation of Karan fries and Karan Swiss cattle under closed breeding system. Asian-Aust. J. Anim. Sci., 17(1): 1-6.

14. Mukherjee, S. (2005) Genetic evaluation of Frieswal cattle. Ph.D. Thesis, National Dairy Research Institute (Deemed University) Karnal, Haryana, India.

15. Nayak, S.K. and Raheja, K.L. (1996) Performance of halfbred and 3-bred crosses of Hariana with exotic dairy breeds. Indian J. Anim. Sci., 66(2): 154-158.

16. Hadge, M.R., Kuralkar, S.V., Ali, S.Z., Kharkar K.P. and Sawaimul, A.D. (2012) Genetic studies on productive traits of Sahiwal and Sahiwal X Jersey crossbred cows. Indian J. Anim. Res., 46(1): 92-94.

17. Rathi, R.C. (1984) Study on inheritance of monthly milk yield and their economics traits in Sahiwal and its crossbred. M.Sc. (Ag.) Thesis, G.B. Pant University of Agriculture and Technology, Pantnager, Uttarakhand, India.

18. Annual Report. (2008-09, 2009-10 and 2010-11) Project Directorate on Cattle, Meerut, India.

19. Butte, S.V. and Deshpande, K.S. (1986) Calving interval in Friesian x Shaiwal crossbreds. Indian J. Anim. Sci., 56(7): 809-810.

20. Kumar, D.K., Reddy, C.E., Gupta, B.R. and Satyanarayana, A. (2003) Effect of year, season and lactation order on the performance of Ongole cattle. Indian $J$. Anim. Sci., 73(11): 1289-1290.

21. Kabir, F. and Islam, M.R. (2009) Comparative study on productive and reproductive performance of local and different crossbred dairy cows at Daulatpur, Khulna in Bangladesh. Bangladesh Res. Publ. J., 3(2): 909-914.

22. Khanna, A.S. and Singh, K. (2003) Association between lactation traits and there MPPA for cows evaluation. Indian J. Anim. Sci., 73(7): 818-819.

23. Tadesse, M. and Dessie, T. (2003) Milk production 
performance of zebu, HF and their crosses in Ethiopia. Livest. Res. Rural Dev., 15(3): 1-19.

24. Dandapat, A., Banerjee, D. and Chakraborty, D. (2010) Genetic studies on various production and reproduction traits of Sahiwal and crossbred cattle (HF $\times$ Jersey $\times$ Sahiwal) of an organized farm. Vet. World, 3(4): $167-168$

25. Chaudhary, R.S. (1983) Study on inheritance of economics characters and genetic divergence in dairy Cows. M.
Sc. (Ag.) Thesis, G. B. Pant University of Agriculture and Technology, Pantnager, Uttarakhand, India.

26. Khan, U.N., Benyshek, L.L. and Ahmad, M.D. (1988) Repeatibility and heritability estimate for economics traits of native and crossbred dairy cattle. Pak. J. Agric. Res.,9(4): 575-579.

27. Saha. (2010) Generation wise genetic evaluation of Karan Swiss and Karan Fries cattle. M.Sc. Thesis. NDRI Deemed University, Karnal, Haryana, India.

$* * * * * * * *$ 